\title{
Somogy megye emlős faunája (Mammalia)
}

\author{
Lanszki József \& Purger J. Jenö
}

\begin{abstract}
LANSZKI J. \& PURGer J. J.: The mammal fauna of Somogy county (Mammalia)
Abstract: In Somogy county 68 mammal species representing $80 \%$ of the Hungarian fauna have been recorded among the 85 species found in Hungary 8 of them are Insectivora, 18 Chiroptera, 2 Lagomorpha, 22 Rodentia, 14 Carnivora and 4 Artiodactyla. Due to the environmental conditions of the county, are expected to disappear in the future. There are some species (mainly Chiroptera) which are not present on our list because the research of them is incomplete. The aim of this review is to present the mammal fauna of Somogy county, based on present research to show the insufficiencies as well.
\end{abstract}

\section{Bevezetés}

Közel száz évvel ezelốtt a Magyar Birodalom állatvilága (Fauna Regni Hungariae) emlősökkel foglalkozó kötetében PASzLAVSZKY (1918) bizonyíthatóan mindössze 7 emlôs faj (üregi nyúl, közönséges hód, nyugati földikutya, aranysakál, nyuszt, vadmacska, dámvad) Somogy megyei előfordulásáról számolt be. A 20. században az emlőstani kutatások Somogy megyében viszonylag szerteágazóvá váltak. Ebben bizonyára sok tényezőnek fontos szerepe volt, pl. az emlő́sök (Mammalia) osztályába a néhány grammos törpecickánytól a 200-300 kg-os gímszarvasig és vaddisznóig növényevő, rovarevő, ragadozó és csúcsragadozó fajok egyaránt megtalálhatók. Vannak közöttük gyakori, sốt kozmopolita, elterjedóben levó, visszatelepülő de kipusztulóban levó fajok, melyek élóhelyi kötődése is nagy változatosságot mutat. Mivel a megye domborzati, vízrajzi, klimatikus és növényzeti feltételei igen változatosak, az itt található fauna is gazdag. Az emlős fajok mező-, hal-, erdő- és vadgazdálkodási jelentősége is nagymértékben különbözik, ami kutatottságukban is megmutatkozik.

Az emlös faunisztikai kutatások eleinte néhány kiemelt jelentőségú területhez, pl. a Baláta-tóhoz, a Barcsi Borókáshoz kapcsolódtak. A Dráva-mente Somogy megyei szakaszának vizsgálata során kapott első kisemlős adat GRESCHIK (1924) munkájában olvasható, aki a gatyásölyv táplálékmaradványait vizsgálta a Barcsi Borókásban. Az 1909-ben gyứjtött anyagból kimutatta a közönséges erdei egeret (Apodemus sylvaticus). A Magyar Természettudományi Múzeum zoológusa, ÉHIK (1919) Inkéból kimutatta a házi patkányt (Rattus rattus). Háromfánál 1925-ben megfogta a csalitjáró pockot (Microtus agrestis) (ÉHIK 1928), a begyújtött példányt ma is a Magyar Természettudományi Múzeum Emlőstani Gyújteményében ôrzik (CSORBA \& DEMETER 1991). A szórványos eseti leírások után (pl. VÁSÁRHELYI 1939) a felméró munka viszonylag késốn, csak az 50-es években kezdődött meg. A megyében faunisztikai vizsgálatot elsốként Marián Miklós végzett az országosan is kiemelt jelentőségư Baláta-tó térségében 1952 és 1957 között (MARIÁN 1957, 1958). Ezt követôen újabb évtizedek teltek el az emlöstani tudományos kutatások folytatásáig. Monitor- 
ing jellegú vizsgálatok csak a 90-es évek második felében indultak, országos szinten ragadozó emlös fajokra (HeLTAI et al. 2000b; SzEMETHY \& HeLTAI 1996), valamint a Kis-Balaton térségében kisemlösökre (LELKES \& HORVÁTH 2000).

Az emlős faunisztikai felmérések egy része közvetett módszerekkel történt. Így került sor különbözô ragadozó madarak (pl. egerészölyv, gatyásölyv), dolmányos varjú és bagolyfajok (gyöngybagoly, erdei fülesbagoly, réti fülesbagoly, macskabagoly és kuvik) köpetanalízisére, melynek fő célja elsősorban a madarak táplálkozásbiológiai vizsgálata volt. Ennek révén a költô és pihenóhelyek környékén a rovarevó és rágcsáló fauna feltérképezése is megtörtént. A módszer alapját a köpetekben található kisemlős maradványok (koponya és/vagy szórszálak), - mint általában domináns táplálékfajok - akár faj szintú határozása jelenti. A feldolgozás során több határozókönyvet (pl. Ács 1985; MÄrz 1972; SCHMIDT 1967; TEERINK 1991; UJHELYI 1989; YALDEN 1977; YALDEN \& MORRIS 1990; ZÖRÉNYI 1990) használnak. Táplálék-összetétel vizsgálat a Barcsi Borókásban, illetve a Dráva mentén (ÉHIK 1928; FENYŐSI 1993, 1994; Greschik 1924; Kalotás 1989; SCHMIDT 1969, 1976; Purger 1998), Gyékényesen (KALOTÁS 1989), a Boronka-melléki Tájvédelmi Körzetben és környékén (Horváth \& LANszKi 2000; MAjer 1992; Purger 1996), a Csokonyavisontai halastavak körzetében (PURGER 1997), Toponáron (Molnár 1993), Répáspusztán (Molnár 1994), Iharosberényben (BITTERA I914; CsIKI 1914; GRESCHIK 1911), Lengyeltótiban (GRESCHIK 1911), Kaposváron és Fonó körzetében (LANSZKI 1999) zajlott.

A bagolyköpet vizsgálatnál kissé komplikáltabb a ragadozó emlősök ürülékanalízise. Tekintettel arra, hogy az ürülékben található emlős maradványok között ritkán fordul elö koponya, ill. állkapocscsont töredék, leggyakrabban a táplálék állatok szórszál morfológiája alapján történik a határozás (TEERINK 1991). Ilyen jellegú vizsgálat - a rendkívül nagy időigényessége miatt - országos viszonylatban is alig zajlott, annak ellenére, hogy jelenleg ragadozó emlósök esetében a legkorszerúbb táplálkozás-ökológiai vizsgálati módszernek tekinthető. A 90-es évek elejétól menyétfélék: nyest (Martes foina), nyuszt (Martes martes), hermelin (Mustela erminea), eurázsiai borz (Meles meles) és vidra (Lutra lutra), valamint kutyafélék: aranysakál (Canis aureus) és vörös róka (Vulpes vulpes) esetében zajlott ragadozó-zsákmány kapcsolat vizsgálata a Boronka-melléki Tájvédelmi Körzetben, Fonó és Mike körzetében (LANSZKI 1999; LANSZKI \& HELTAI 2000; LANSZKI \& KÖRMENDI 1996a, 2000a, 2000b; LANSZKI et al. 1999). Említést érdemel a fokozottan védett vidra (Lutra lutra) táplálkozási szokásainak Somogy megyei élóhelyekhez kötôdő tanulmányozása (LANSZKI \& KÖRMENDI 1996a, 1996b, 1996c, 2000a).

Gyomortartalom vizsgálati eredmények a vadászható vörös rókával kapcsolatban állnak rendelkezésre (HELTAI et al. 2000).

A megye több pontján begyújtött emlösökön szerteágazó parazitológiai vizsgálatokat végeztek (AMBROS 1982; BERON 1965; HAITLINGER 1973; KOVÁČIK 1982; Mahunka 1963; Mahunka \& Molnos 1962; Mészáros 1971, 1978; MÉSzÁros \& SugÁr 1976; Molnos 1982; MuraI 1972, 1974, 1976; Murai \& Sugár 1976; Murai \& Tenora 1972; Murai et al. 1975; Sey, 1964, 1965, 1990, 1991; SUGÁr I976a, 1976b, 1978; SugÁr \& MATSKÁSI 1978; Sugár \& MÉSzÁros 1975; SzABó 1965, 1969; SzAPPANOS \& PAPP 19991.).

A kérdőíves felméréses módszer gyors, nagy mennyiségú adat nyerését teszi lehetővé. Viszonylag olcsó megoldás faunisztikai felmérés céljára, amennyiben a válaszadók köre megbízható. A felmérésekben szereplő egyik legfontosabb 


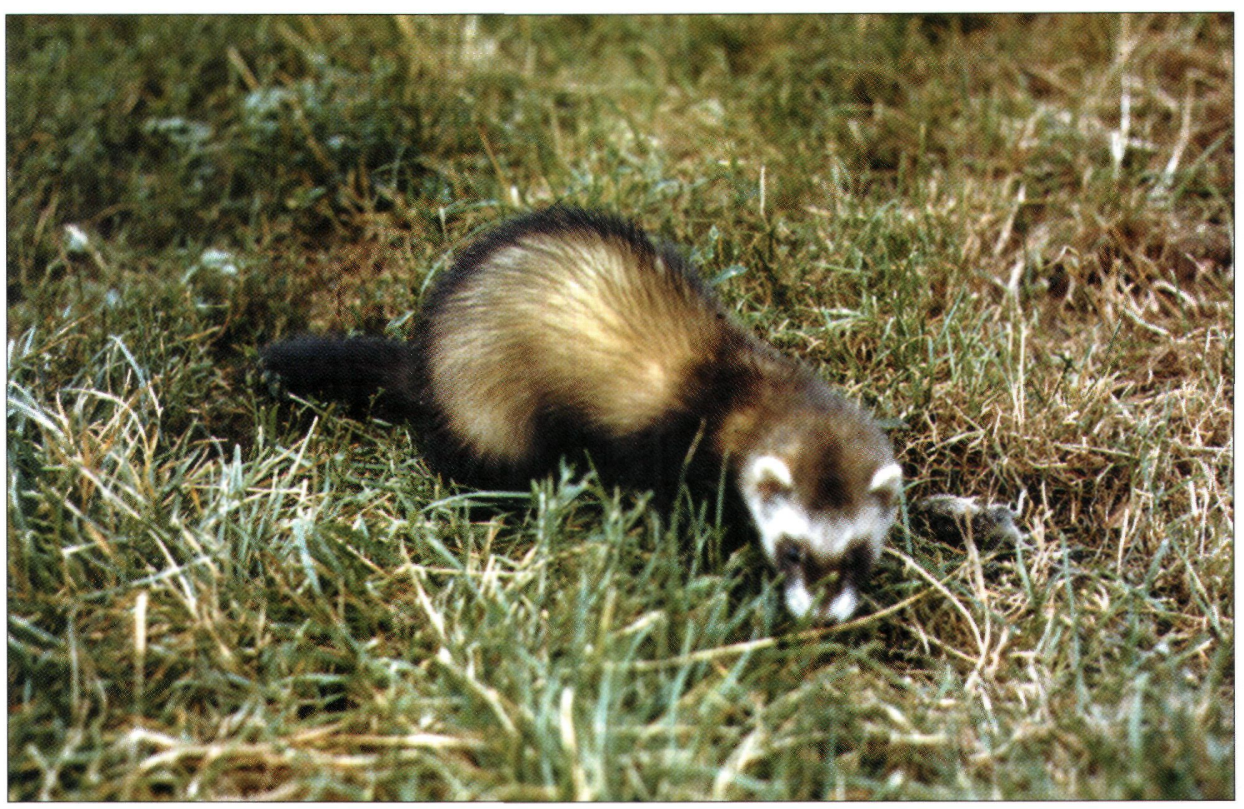

l. ábra: Közönséges görény (Mustela putoris) Fotó: Lanszki J.

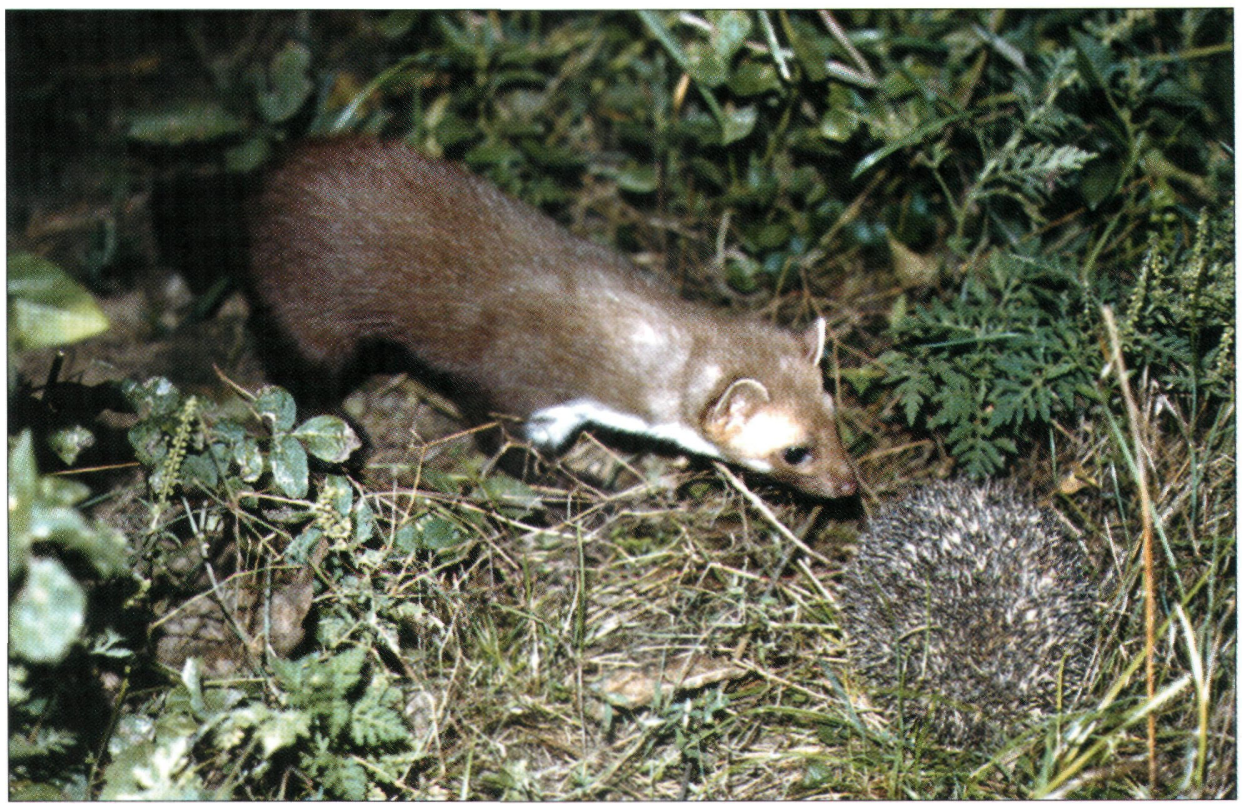

2. ábra: Nyest - Martes foina és sün - Erinaceus concolor Fotó: Lanszki J. 


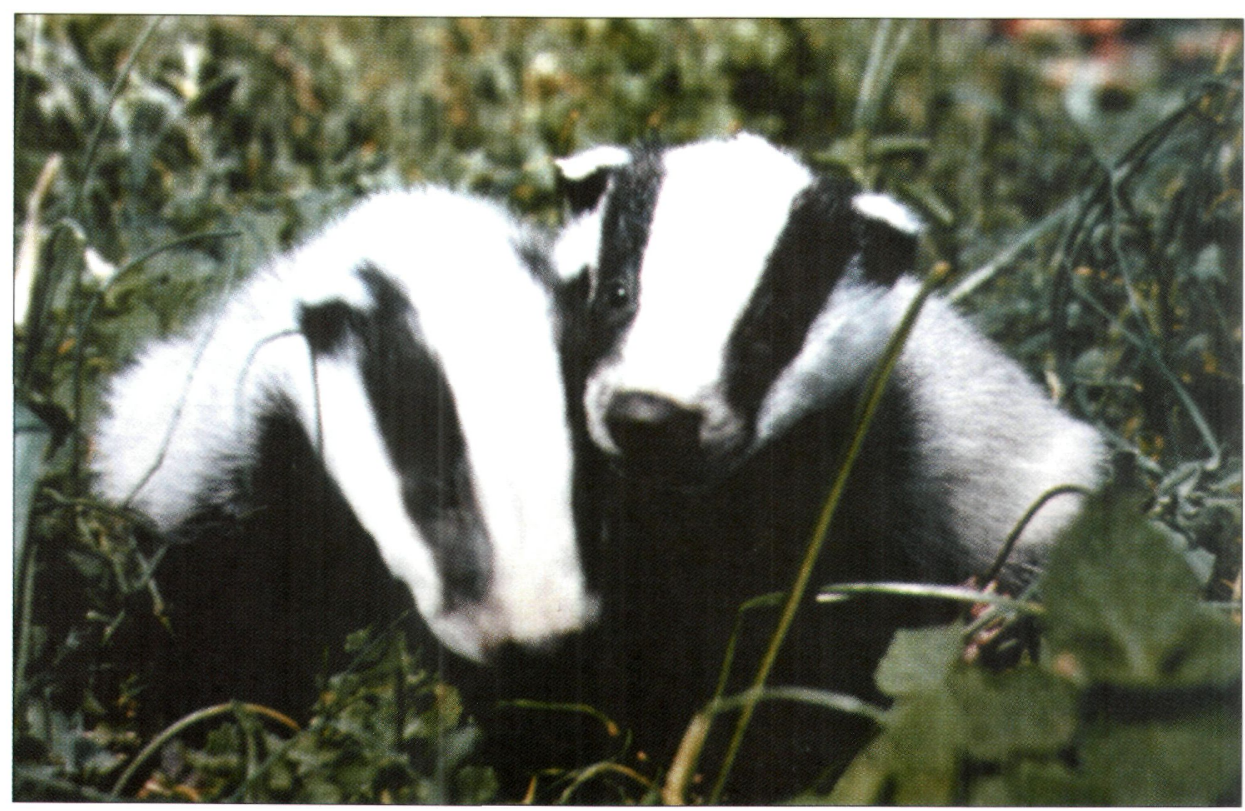

3. ábra: Borzok - Meles meles Fotó: Lanszki J.

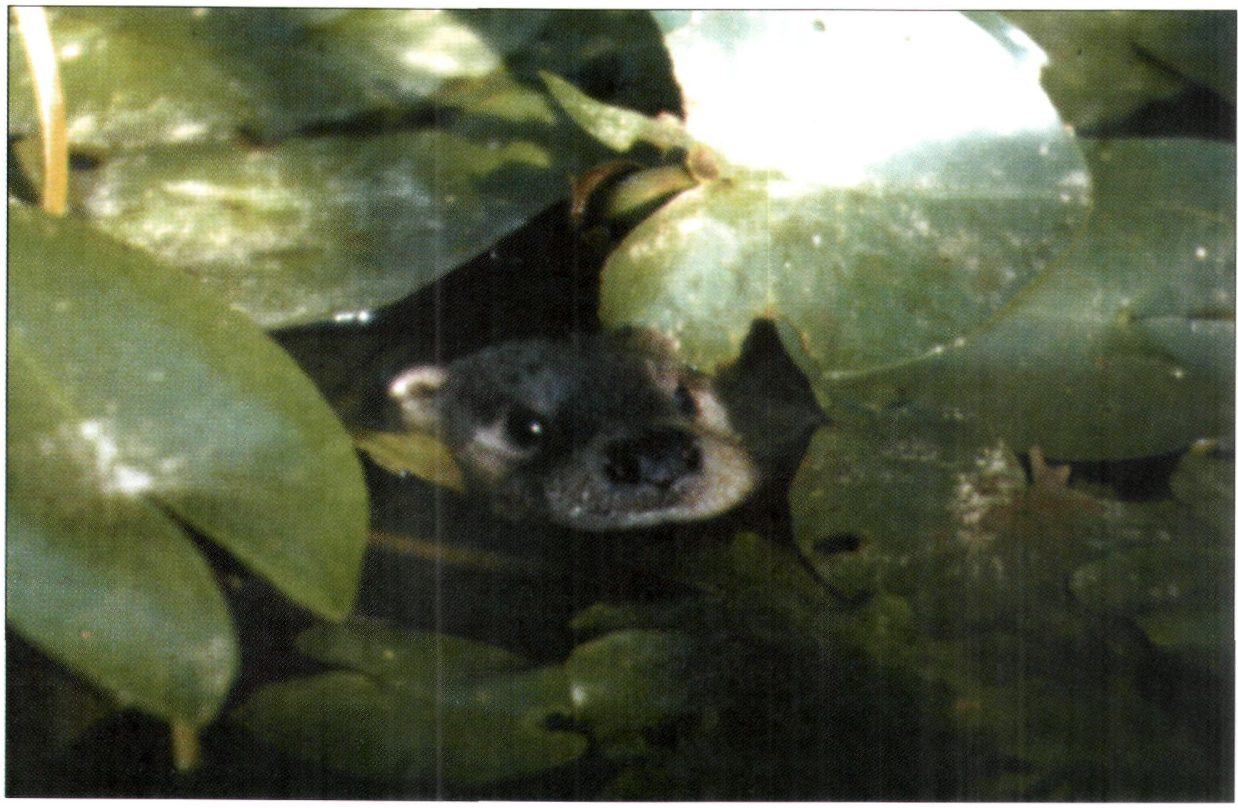

4. ábra: Vidra - Lutra lutra Fotó: Lanszki J. 
fajnak, az Európa szerte veszélyeztetett vidrának a legjelentősebb hazai élóhelyei a Dél-Dunántúlon találhatók. Kérdőíves felméréseket két különbözó módszerrel 1988 és 1999 között végeztek (ANONYMUS 1996, 1999; SZEMETHY \& Heltai 1996). A vidrán kívül kérdőíves felmérésben szerepelt a vörösróka, a vadmacska (Felis silvestris), az eurázsiai borz, a nyuszt, az aranysakál, az északamerikai mosómedve (Procyon lotor) és a nyestkutya (Nyctereutes procyonoides) (CSÁNYI 1996, 1999; HelTAI et al. 2000b; Szemethy \& Heltai 1996). A kistestû́ menyétfélék egy részérool (eurázsiai menyét, hermelin, közönséges görény, molnár görény, nyest) azonban szinte semmilyen elterjedési adat nem áll rendelkezésünkre.

Közvetlen módszerrel történô kisemlôs faunisztikai, populációdinamikai és élőhely preferencia vizsgálat a Kis-Balaton térségében folyt (LELKES \& HORVÁTH 2000). A Kis-Balatonon ÉHIK (1952) már az 50-es évek elején fogott be patkányfejú pockot (Microtus oeconomus). Fogás-jelölés-visszafogás módszerrel elevenfogó csapdázás Somogy megyében mindössze a Boronka-melléki Tájvédelmi Körzetben (HoRvÁTH \& LANSZKI 2000) történt. Ennek a több éves OTKA kutatásnak a fớ célja a ragadozó és zsákmánya közötti kapcsolatok vizsgálata volt.

Ritka ragadozó emlósökre vonatkozó Somogy megyei adatok közül az Iharosberényben (ÉHIK 1934, 1956; FARAGó 1989), Ropolyi erdóben, Tótfaluban, Ladon (Faragó 1989), és Somogyjádon (Muray \& Sugár 1976) kézre került, vagy megfigyelt farkas (Canis lupus) kiemelt figyelmet érdemel. A 90-es években több alkalommal is megfigyeltek (HeLTAI et al. 2000) jövevény fajokat, így az észak-amerikai mosómedvét és a nyestkutyát. A Magyar Vörös Könyvben (RAKONCZAY 1990), a kipusztult fajok listáján szereplő aranysakál (régies nevén nádi farkas) az 1990-es években visszatelepült a Dél-Dunántúlra (Gellai Tibor, Novotny Zsolt és Pintér András szóbeli közlése, HeltAI et al. 2000; LANSZKI \& HeLTAI 2000; SIMON 1996). Az országos ragadozó emlós biomonitoringban helyet kaptak olyan Somogy megyei mintaterületek (Fonyód, Zics, Gyékényes-Lankóci erdő), melyeken elevenfogó ragadozó emlős és kisemlős csapdázás zajlik faunisztikai és populáció-dinamikai felmérés érdekében.

Közvetlen megfigyelés és gyứités a Baláta-tó körzetében (MARIÁN 1957, 1958, MAJER 1992a), Csokonyavisontán és Háromfán házi patkány esetében (Jabir et al. 1985) történt. További értékes megfigyelési adatok állnak rendelkezésre a Baláta-tó TT, a Barcsi Borókás TK, a Boronka-melléki TK, a DunaDráva NP, a Csokonyavisontai TT, a Nagyberek-Fehérvíz TT. A Látránypuszta TT, a Zákányi dombok TT és a Zselici TK területéról (Ábrahám et al., 1994). Néhány évtizeddel ezelött még elófordult a közönséges hörcsög (Cricetus cricetus), azonban az utóbbi idôben a megyében nem bizonyítható az előfordulása. Jelentősen megritkult a közönséges ürge (Citellus citellus) állománya. Az utóbbi években a Dráva és a Mura folyó mentén, több esetben hód (Castor fiber) rágásnyomok megfigyelése történt, ami elsősorban a sikeres (vissza)telepítést bizonyítja.

Bár több hazai adatbázis is rögzít denevér faunisztikai adatokat, a megfigyelések eredményét mindössze néhány esetben publikálták. A kis számú publikáció egyik fố oka lehet a denevér populációk megvédése. Annak ellenére, hogy megfogyatkozott állományaik teljes védelem alatt állnak, a babonás nézetek fennmaradása miatt az emberektól ma sincsenek teljes biztonságban.

Említésre méltó Somogy megye nagy múltra visszatekintố vadállománya. Világhírú a gímszarvas, a vaddisznó, a dámvad és az ôzállomány. A vadászati, 
vadgazdálkodási eredményeket, érmes trófeákat számtalan szakcikk és könyv dokumentálja, melyek közül csak a faunisztikai feldolgozásokat említjük (pl. BOD 1994; CSÁNYI 1996). A megyében alkotott Studinka László, Cséplô József és Páll Endre vadászíró. A Göllében született Fekete István (1900-1970) csodálatos regényeiben, novelláiban eleveníti meg szülőföldjének természeti kincseit.

A fentiekből is látható, hogy a megyében az emlöstani kutatás idônként lendületet kapott ugyan, azonban a vizsgálatok fôként egyes területekhez kötődtek és jelentôs fehér foltok maradtak, különösen Külső-Somogyban. Ennek okai között említhetô, hogy a komplex (életközösségi szintû) ökológiai vizsgálat rendkívül idô- és eszközigényes. Az emlős fajok jelentős része éjszakai, vagy rejtőzködố életmódot él, a megfigyelésük és nyomon követésük nem egyszerú feladat.

\section{Somogy megye emlős fajainak jegyzéke}

A fajok magyar- és tudományos neve, valamint rendszertani sorrendje MITCHELL-JONES et al. (1999) munkája alapján adjuk meg. Az irodalmi hivatkozások pedig nem az időrendi, hanem az $\mathrm{ABC}$ sorrendet követik.

ROVAREVÖK - INSECTIVORA

1. Keleti sün - Erinaceus concolor (Martin, 1838) - Ábrahám et al. 1994; Greschik 1924; Majer 1992a; Marián 1957; Nagy \& Pintér 1994.

2. Erdei cickány - Sorex araneus (Linnaeus, 1758) - Ambros 1982; Ábrahám et al. 1994; Fenyósi 1994; Horváth 1998; Horváth \& Lanszki 2000; Kalotás 1989; Lanszki 1999; Lanszki \& Körmendi 2000; Lelkes 1994; Majer 1992a, 1992b; Marián 1957, 1958; Nagy 1988; Nagy \& Pintér 1994; Purger 1996. 1997, 1998; Schmidt 1969, 1973, 1976; Szabó 1969

3. Törpecickány - Sorex minutus (Linnaeus, 1766) - Ábrahám et al. 1994; Fenyốsi 1994; Horváth 1998; Kalotás 1989; Lelkes I994; Majer 1992a, 1992b; Marián 1957; Nagy 1988; Nagy \& Pintér 1994; Purger 1996, 1997, 1998; Schmidt 1969, 1973, I976; Szabó 1969 .

4. Miller-1ízicickány - Neomys anomalus (Cabrera, 1907) - Ábrahám et al. 1994; Horváth 1998; Kalotás 1989; Lelkes 1994; Majer 1992a, 1992b; Marián 1957; Nagy \& Pintér 1994; Purger 1996, 1997, 1998; Schmidt 1969.

5. Közönséges vízicickány - Neomys fodiens (Pennant, 1771) - Ábrahám et al. 1994; Fenyôsi 1994; Horváth 1998; Kalotás 1989; Lanszki 1999; Lelkes 1994; Majer 1992a, 1992b; Nagy \& Pintér 1994; Purger 1996, 1998; Szabó 1969.
6. Mezei cickány - Crocidura leucodon (Hermann, 1780) - Ábrahám et al. 1994; Fenyósi 1994; Horváth 1998; Kalotás 1989; Lanszki 1999; Lelkes 1994; Majer 1992a, 1992 b; Marián 1957; Nagy 1988; Nagy \& Pintér 1994; Purger 1996, 1997, 1998; Schmidt 1969, 1973, 1976.

7. Keleti cickány - Crocidura suaveolens (Pallas, 1811) - Ábrahám et al. 1994; Fenyősi 1994; Horváth 1998; Kalotás 1989; Lanszki \& Körmendi 1999; Lelkes 1994; Majer 1992a, 1992b; Nagy \& Pintér 1994; Purger 1996, 1997, 1998; Schmidt 1969, 1973, 1976.

8. Közönséges vakond - Talpa europaea (Linnaeus, 1758) - Ábrahám et al. 1994; Greschik 1911, 1924; Fenyősi 1993; Kalotás 1989; Lanszki 1999; Lanszki \& Körmendi 1999; Majer 1992a, 1992b; Marián 1957; Nagy \& Pintér 1994; Purger 1996, 1998; Schmidt 1969, 1976; Szabó I969.

\section{Denevérek - Chiroptera}

9. Nagy patkósdenevér Rhinolophus ferrumequinum (Schreber, 1774) - Ábrahám et al. 1994; Nagy \& Pintér 1994.

10. Kis patkósdenevér Rhinolophus hipposideros (Bechstein, 1800) - Ábrahám et al. 1994; Nagy \& Pintér 1994.

11. Nagyfülü denevér - Myotis bechsteinii (Kuhl, 1817) - Ábrahám et al. 1994; Somogyvári \& Dombi 2001; Szabó 1965. 
12. Hegyesorrú denevér - Myotis blythii (Tomes, 1857) - Ábrahám et al. 1994; Nagy \& Pintér 1994; Somogyvári \& Dombi 2001; Topál 1956.

13. Brandt-denevér - Myotis brandtii (Eversmann, 1845) - Ábrahám et al. 1994; Nagy \& Pintér 1994; Somogyvári \& Dombi 2001; Szabó 1965, 1969.

14. Vizi denevér - Myotis daubentonii (Kuhl, 1817) - Ábrahám et al. 1994; Nagy \& Pintér 1994; Somogyvári \& Dombi 2001.

15. Közönséges denevér - Myotis myotis (Borkhausen, 1797) - Ábrahám et al. 1994; Mészáros 1971; Murai 1976; Nagy \& Pintér 1994; Purger 1998; Somogyvári \& Dombi 2001.

16. Bajuszos denevér - Myotis mystacinus (Kuhl, 1817) - Marián 1957, 1958; Purger 1996; Somogyvári \& Dombi 2001.

17. Horgasszörü denevér - Myotis nattereri (Kuhl, 1817) - Purger 1998; Somogyvári \& Dombi 2001 .

18. Fehérszélü törpedenevér - Pipistrellus kuhlii (Kuhl, 1817) - Somogyvári \& Dombi 2001.

19. Durvavitorlájú törpedenevér - Pipistrellus nathusii (Keyserling \& Blasius, 1839) - Marián 1957, 1958; Somogyvári \& Dombi 2001.

20. Közönséges törpedenevér - Pipistrellus pipistrellus (Schreber, 1774) - Ábrahám et al. 1994; Nagy \& Pintér 1994; Somogyvári \& Dombi 2001.

2I. Szốröskarú koraidenevér - Nyctalus leisleri (Kuhl, 1817) - Nagy \& Pintér 1994; Somogyvári \& Dombi 2001.

22. Közönséges koraidenevér - Nyctalus noctula (Schreber, 1774) - ヘ́brahám et al. 1994; Beron 1965; Lanszki 1999; Nagy \& Pintér 1994; Purger 1997; Somogyvári \& Dombi 2001; Szabó 1969.

23. Közönséges késeidenevér - Eptesicus serotinus (Schreber, 1774) - Ábrahám et al. 1994; Majer 1992a; Nagy \& Pintér 1994; Purger 1998; Somogyvári \& Dombi 2001; Topál 1962.

24. Piszedenevér - Barbastella barbastellus (Schreber, 1774) - Somogyvári \& Dombi 2001.

25. Barna hosszúfülü-denevér Plecotus auritus (Linnaeus, 1758) - Mészáros 1971; Somogyvári \& Dombi 2001.

26. Szürke hosszúfülü-denevér - Plecotus ausriacus (J. B. Fischer, 1829) - Ábrahám et al. 1994; Murai 1976; Purger 1996, 1998; Somogyvári \& Dombi 2001; Topál 1965.

\section{NYÚLALAKÚAK - LAGOMORPHA}

27. Mezei nyúl - Lepus europaeus (Pallas, 1778) - Bittera 1914; Csányi 1996; Heltai et al. 2000a; Lanszki 1999; Lanszki \& Körmendi 1999; Lanszki et al. 1999; Marián 1957; Vásárhelyi 1939.

28. Üregi nyúl - Oryctolagus cuniculus (Linnaeus, 1758) - Paszlavszky 1918; Vásárhelyi 1939.

\section{RÁGCSÁLÓK - RODENTIA}

29. Közönséges mókus - Sciurus vulgaris (Linnaeus, 1758) - Ábrahám et al. 1994; Lanszki 1999; Lanszki \& Körmendi 1999, 2000; Marián 1957; Nagy \& Pintér 1994; Vásárhelyi 1939.

30. Közönséges ürge - Spermophilus citellus (Linnaeus, 1766) - Ábrahám et al. 1994; Nagy \& Pintér 1994.

31. Közönséges hód - Castor fiber (Linnaeus, 1758) - Paszlavszky 1918.

32. Közönséges hörcsög - Cricetus cricetus (Linnaeus, 1758) - Vásárhelyi 1939.

33. Vöröshátú erdeipocok - Clethrionomys glareolus (Schreber, 1780) - Ambros 1982; Fenyốsi 1994; Haitlinger 1973; Horváth 1998; Horváth \& Lanszki 2000; Kalotás 1989; Kováčik 1982; Lanszki 1999; Lanszki \& Körmendi 1999, 2000; Lanszki et al. 1999; Lelkes 1994; Majer 1992a, 1992b; Marián 1957, 1958; Mészáros 1978; Molnos 1982; Purger 1996, 1997, 1998; Schmidt 1969, 1976; Szabó 1969; Vásárhelyi 1939.

34. Közönséges kószapocok - Arvicola terrestris (Linnaeus, 1758) - Ambros 1982; Fenyósi 1994; Horváth 1998; Kováčik 1982; Lanszki 1999; Lanszki \& Körmendi 1999; Lanszki et al. 1999; Lelkes 1994; Majer 1992a, 1992b; Marián 1957; Nagy 1982; Purger 1996, 1998; Schmidt 1969, 1976; Vásárhelyi 1939.

35. Pézsmapocok - Ondatra zibethicus (Linnaeus, 1766) - Lanszki 1999; Lanszki \& Körmendi 1996a, 1999, 2000; Lanszki et al. 1999; Marián 1957; Sey 1964, 1965 1990; Vásárhelyi 1939.

36. Csalitjáró pocok - Microtus agrestis (Linnaeus, 1761) - Ambros 1982; Ábrahám et al. 1994; Csorba \& Demeter 1991; Éhik 1928; Fenyősi 1994; Horváth 1998; Kalotás 1989; Kováčik 1982; Lanszki 1999; Lanszki \& Körmendi 1999; Lelkes 1994; Majer 1992a, 1992b; Marián 1957, 1958; Molnár 1993; Nagy 1988; Nagy \& Pintér 1994; Purger 1996, 1997, 1998; Schmidt 1969, 1974c; Szabó 1969.

37. Mezei pocok - Microtus arvalis (Pallas, 1778) - Bittera 1914; Csiki 1914; Fenyősi 1994; Greschik 1911, 1924; Horváth 1998; 
Kalotás 1989; Lanszki 1999; Lanszki \& Körmendi 1996a, 1999; Lanszki et al. 1999; Lelkes 1994; Majer 1992a; Marián 1957; Molnár 1993; Nagy 1982, 1988; Purger 1996, 1997, 1998; Schmidt 1974a, 1976; Szabó 1969; Vásárhelyi 1939.

38. Északi pocok - Microtus oeconomus (Pallas, 1776) - Ábrahám et al. 1994; Éhik 1952; Lelkes 1994; Nagy 1982; Nagy \& Pintér 1994; Schmidt 1969; Szabó 1969.

39. Közönséges földipocok - Microtus subterraneus (de Sélys-Longchamps, 1836) - Fenyösi 1994; Horváth 1998; Kalotás 1989; Lanszki 1999; Lanszki \& Körmendi 1999; Lelkes 1994; Majer 1992a; Molnár 1993; Nagy 1982, 1988; Purger 1996, 1997, 1998; Schmidt 1969, 1974d.

40. Nyugati foldikutya - Nannospalax leucodon (Nordmann, 1840) - Csorba \& Demeter 1991; Paszlavszky 1918.

41. Törpeegér - Micromys minutus (Pallas, 1771) - Fenyősi 1994; Horváth 1998; Kalotás 1989; Lanszki 1999; Lanszki \& Körmendi 1999; Lelkes 1994; Majer 1992a, 1992b; Nagy 1982, 1988; Purger 1996, 1997, 1998; Schmidt 1969, 1976.

42. Pirók erdeiegér - Apodemus agrarius (Pallas, 1771) - Fenyősi 1994; Horváth 1998; Horváth \& Lanszki 2000; Kalotás 1989; Lanszki 1999; Lanszki \& Körmendi 1999; Lanszki et al. 1999; Majer 1992a, 1992b; Marián 1957, 1958; Murai 1972; Nagy 1982, 1988; Purger 1996, 1997, 1998; Schmidt 1969, 1976; Szabó 1969; Vásárhelyi 1939.

43. Sárganyakú erdeiegér - Apodemus flavicollis (Melchior, 1834) - Haitlinger 1973; Horváth \& Lanszki 2000; Lanszki 1999; Lanszki \& Körmendi 1999, 2000; Lanszki et al. 1999; Marián 1957, 1958; Molnos 1982; Murai I972; Murai \& Tenora 1972; Purger 1996, 1997, 1998; Szabó 1969 .

44. Közönséges erdeiegér - Apodemus sylvaticus (Linnaeus, 1758) - Greschik 1911, 1924; Haitlinger 1973; Horváth \& Lanszki 2000; Lanszki 1999; Lanszki \& Körmendi 1999, 2000; Lanszki et al. 1999; Mahunka 1963; Mahunka \& Molnos 1962; Marián 1958; Molnos 1982; Murai 1972; Purger 1996, 1997. 1998; Vásárhelyi 1939.

45. Vándorpatkány - Rattus norvegicus (Berkenhout, 1769) - Fenyósi 1994; Horváth 1998; Lanszki 1999; Lanszki \& Körmendi 1999; Lanszki et al. 1999; Majer 1992b; Purger 1996, 1998; Vásárhelyi 1939.

46. Házi patkány - Rattus rattus (Linnaeus, 1758) - Éhik 1919; Jabir et al.1985; Purger
1997; Vásárhelyi 1939.

47. Házi eģér - Mus musculus (Linnaeus, 1758) - Fenyốsi 1994; Horváth 1998; Kalotás 1989; Lanszki 1999; Lanszki \& Körmendi 1996a, 1999; Lanszki et al. 1999; Lelkes 1994; Majer 1992a, 1992b; Marián 1957, 1958; Nagy 1982, 1988; Purger 1996, 1997; Schmidt $1969,1976$.

48. Güzü egér - Mus spicilegus (Petényi, 1882) - Horváth 1998; Szabó 1969; Vásárhelyi 1939.

49. Nagy pele - Glis glis (Linnaeus, 1766) Ábrahám et al. 1994; Horváth \& Lanszki 2000; Lanszki 1999; Lanszki \& Körmendi 2000; Nagy \& Pintér 1994; Purger 1998.

50. Mogyorós pele - Muscardinus avellanarius (Linnaeus, 1758) - Ábrahám et al. 1994; Bakó 1996; Bakó et al. 1998; Fenyősi 1994; Horváth 1998; Horváth \& Lanszki 2000; Kalotás 1989; Lanszki 1999; Lanszki \& Körmendi 1999; Lanszki et al. 1999; Majer 1992a, 1992b; Marián 1957; Molnár 1994; Nagy \& Pintér 1994; Purger 1996, 1997, 1998; Schmidt 1974b.

\section{RAGADOZÓK - CARNIVORA}

51. Aranysakál - Canis aureus (Linnaeus, 1758) - Heltai et al. 2000b; Lanszki 1999; Lanszki \& Heltai 2000; Paszlavszky 1918; Simon 1996.

52. Farkas - Canis lupus Linnaeus, 1758 Éhik 1934, 1956; Faragó 1989; Muray \& Sugár 1976.

53. Vörös róka - Vulpes mulpes (Linnaeus, 1758) - Csányi 1996, 1999; Heltai et al. 2000a; Lanszki 1999; Lanszki \& Körmendi 1996a, 1999, 2000; Lanszki et al. 1999; Marián 1957; Szabó 1969; Vásárhelyi 1939.

54. Nyestkutya - Nyctereutes procyonoides (Gray, 1834) - Heltai et al. 2000b.

55. Észak-amerikai mosómedve - Procyon lotor (Linnaeus, 1758) - Heltai et al. 2000b.

56. Hermelin - Mustela erminea (Linnaeus, 1758) - Ábrahám et al. 1994; Lanszki 1999; Lanszki \& Körmendi 1996a, 1999; Lanszki et al. 1999; Nagy \& Pintér 1994.

57. Molnárgörény - Mustela eversmanii (Lesson, 1827) - Vásárhelyi 1939.

58. Eurázsiai menyét - Mustela nivalis (Linnaeus, 1766) - Ábrahám et al. 1994; Greschik 1911; Majer 1992a, 1992b; Marián 1957; Nagy \& Pintér 1994; Vásárhelyi 1939.

59. Közönséges görény - Mustela putorius (Linnaeus, 1758) - Majer 1992a; Marián 1957; Sugár \& Matskási 1978; Vásárhelyi 1939. 
60. Nyest - Martes foina (Erxleben, 1777) Csányi 1999; Lanszki 1999; Lanszki \& Körmendi 1996a, 1999; Lanszki et al. 1999; Majer 1992a; Marián 1957, 1958.

61. Nyuszt - Martes martes (Linnaeus, 1758) Ábrahám et al. 1994; Kalotás 1996; Lanszki 1999; Lanszki \& Körmendi 2000; Majer 1992b; Nagy \& Pintér 1994; Szemethy \& Heltai 1996; Paszlavszky 1918.

62. Eurázsiai borz - Meles meles (Linnaeus, 1758) - Ábrahám et al. 1994; Lanszki 1999; Lanszki \& Körmendi 1999, 2000; Lanszki et al. 1999; Marián 1957, 1958; Nagy \& Pintér 1994; Szemethy \& Heltai 1996; Vásárhelyi 1939.

63. Vidra - Lutra lutra (Linnaeus, 1758) Anonymus 1996, 1999; Lanszki 1999; Lanszki \& Körmendi 1996a, 1996b, 1996c, 1999, 2000; Lanszki et al. 1999; Majer 1992a; Marián 1957; Nagy 1996; Nagy \& Pintér 1994; Szemethy \& Heltai 1996; Vásárhelyi 1939.

64. Vadmacska - Felis silvestris Schreber, 1775 - Ábrahám et al. 1994; Kalotás 1996; Marián 1957, 1958; Nagy \& Pintér 1994; Paszlavszky 1918; Szemethy \& Heltai 1996; Vásárhelyi 1939.
PÁROSUIJÚ PATÁSOK - ARTIODACTYLA

65. Vaddisznó - Sus scrofa Linnaeus, 1758 Bakkay, 1971; Csányi 1996, 1999; Lanszki 1999; Lanszki \& Körmendi 1999, 2000; Lanszki et al. 1999; Marián 1957, 1958.

66. Dámszarvas - Dama dama (Linnaeus, 1758) - Bakkay, 1971; Csányi 1996, 1999; Lanszki 1999; Marián 1957, 1958; Paszlavszky 1918; Sey 1991;

67. Gímszarvas - Cerrus elaphus Linnaeus, 1758 - Bakkay, 1971; Bod 1994; Bod \& Szabó 1996; Csányi 1996, 1999; Lanszki 1999; Lanszki \& Körmendi 1999, 2000; Marián 1957, 1958; Sey 1991; Sugár 1976a; Sugár \& Mészáros 1975; Szappanos \& Papp 1991; Vásárhelyi 1939.

68. Európai öz - Capreolus capreolus (Linnaeus, 1758) - Bakkay, 1971; Csányi 1996, 1999; Fenyősi 1993; Lanszki 1999; Lanszki \& Körmendi 1996a, 1999, 2000; Lanszki et al. 1999; Marián 1957, 1958; Mészáros \& Sugár 1976; Murai et al. 1975; Sey 1991; Sugár 1976b; Vásárhelyi 1939.

Az országban előforduló 85 emlős faj (KorSós \& MéSZÁROS 1998) közül 68 él, vagy élt (80\%) Somogy megyében (1. táblázat).

A 20. század utolsó évtizedében a megyében az emlôstani kutatásokat erôteljes fellendülés jellemezte és reméljük, hogy ez a tendencia tovább fog folytatódni. Új nemzeti parkok alakultak (Duna-Dráva NP, Balaton-Felvidéki NP). A Somogy Megyei Múzeumok Igazgatóságának Természettudományi Osztályán (Kaposvár) és a Janus Pannonius Múzeum Természettudományi Osztályán (Pécs) a kutatások szervezésére és koordinálására mind nagyobb hangsúlyt fektetnek. A Kaposvári Egyetem és a Pécsi Tudományegyetemen dolgozó kutatók pedig mind gyakrabban a csapatmunkát, tapasztalatcserét helyezik előtérbe, így próbálják eredményesebbé és sikeresebbé tenni munkájukat.

1. táblázat. Az emlős fajok számának megoszlása Magyarországon és Somogy megyében.

\begin{tabular}{|l|c|c|}
\hline Rend (Ordo) & Magyarország & Somogy megye \\
\hline Rovarevök (Insectivora) & 9 & 8 \\
\hline Denevérek (Chiroptera) & 26 & 18 \\
\hline Nyúlalakúak (Lagomorpha) & 2 & 2 \\
\hline Rágcsálók (Rodentia) & 26 & 22 \\
\hline Ragadozók (Carnivora) & 15 & 14 \\
\hline Párosujiú patások (Artiodactyla) & 7 & 4 \\
\hline Össszesen & 85 & 68 \\
\hline
\end{tabular}




\section{Köszönetnyilvánítás}

Köszönjük Bihari Zoltánnak, Büki Józsefnek és Csorba Gábornak az irodalom begyújtése során nyújtott önzetlen segítséget.

\section{Irodalom}

ANONYMUS 1996: Jelentés „a fokozottan védett és veszélyeztetett vidra országos állományfelmérése" címú 1153/K nyilvántartási számú K+F szerződés teljesítésérôl (1996). - Alapítvány a Vidrákért.

ANONYMUS 1999: Jelentés a fokozottan védett és veszélyeztetett vidra (Lutra lutra Linnaeus, 1758) állományának országos felméréséról (1998-99). - Alapítvány a Vidrákért.

Amiros, M. 1982: Three species of mites (Acari: Mesostigmata) parasiting small mammals in Hungary. - Parasit. hung. 14: 95-97.

Ábrahám, L. JuhÁsz, M. PinTér, A. NAGY, L. 1994: Védett természeti értékek Somogyban. - Múzeumi Tájékoztató (Kaposvár) 4: 3-70.

Ács, A. 1985: A bagolyköpetvizsgálatok alapjai. - A Magyar Madártani Egyesület Zalai Helyi Csoportjának kiadványa, Zalaegerszeg, $58 \mathrm{pp}$.

BAKKAY, L. KozMA, Gy. Szúcs, F. (szerk.) 1971: Trófea katalógus. Vadászati Világkiállítás. Budapest, $527 \mathrm{pp}$.

BAKÓ, B. Z. 1996: Adatok a magyarországi pelefajok morfológiájához, elterjedéséhez és ökológiájához. - Diplomadolgozat, JPTE TTK, Pécs, $66 \mathrm{pp}$.

BAKó, B. CsORBA, G. BERTY, L. 1998: Distribution and ecological requirements of dormouse species occuring in Hungary. - Nat. Croat. 7(1): 1-9.

BÁLDI, A. CSORBA, G. KORSós, Z. 1995: Magyarország szárazföldi gerinceseinek természetvédelmi szempontú értékelési rendszere. - Magyar Természettudományi Múzeum, Budapest, 59 pp.

Beron, P. 1965: Contribution a' l'étude des Acariens parasites des Chiroptéres en Hongrie (Spinturnicidae, Trombiculidae, Myobiidae et Acaridae). - Vertebrata Hung. 7(1-2): 141-152.

BITTERA, GY. 1914: Nappali ragadozó madaraink gyomortartalom-vizsgálata. - Aquila 21: 230-238.

BoD, L. 1994: A Somogyi szarvas. - Lipták Vadászati és Kereskedelmi Bt kiadása, Balatonfenyves, 544 pp.

BOD, L., SzABÓ, L. 1996: A Somogy megyei szarvas állomány létszámának és hasznosításának dinamikája 1972-1994. közöı. - Vadbiológia 5: 18-28.

CsánYı, S. (szerk.) 1996: Vadgazdálkodási adattár 1960-1995. Az Országos Vadgazdálkodási Adattár kiadványa. - GATE Vadbiológiai és Vadgazdálkodási Tanszék Gödöllö, 240 pp.

CsánYI, S. (szerk.) 1999: Vadgazdálkodási Adattár 1994-1998. Az Országos Vadgazdálkodási Adattár kiadványa. - GATE Vadbiológiai és Vadgazdálkodási Tanszék Gödölloo. 77 pp.

CSIKI, E. 1914: Biztos adatok madaraink táplálkozásáról. 9. közlemény. - Aquila 21: 210-229.

Csorba, G. Demeter, A. 1991: Annotated list of type specimens of recent mammals in the Hungarian Natural History Museum. - Miscnea zool. hung. 6: 77-85.

ÉHIK, GY. 1919: A házi patkány újabb termőhelyérôl Magyarországon. - Állattani Közlemények $18(1-4): 45-46$.

ÉHIK, GY. 1928: Néhány adat Magyarország emlősfaunájának ismeretéhez. - Ann.hist.-nat.Musei natn.hung. 25: 195-203.

ÉHIK, GY. 1934: A farkas (Canis lupus L.) péniszcsontjáról. - Állattani Közlemények 31 (1-2): 88-91.

ÉHIK, GY. 1952: The occurence of the root-vole (Microtus oeconomus Pall.) at the Kisbalaton. Ann. hist.-nat. Musei natn. Hung. 3: 251-256.

ÉHIK, GY. 1956: Néhány súlyadat emlőseink ismeretéhez. - Állattani Közlemények 45:3-4: 69.

FARAGÓ, S. 1989: A farkas (Canis lupus Linné, 1758) 1920-1985 közötti előfordulása Magyarországon. - Fol. Hist.-nat. Mus. Matr. 14:139-164.

FENYốSı, L. 1993: Adatok az egerészölyv (Buteo buteo) táplálkozásához. - Mad. Táj. 1: 17.

FENYösı, L. 1994: Adatok a gyöngybagoly (Tyto alba) Somogy megyei táplálkozásához. - Mad.

Táj. 2: 30-32. 
GRESCHIK, J. 1911: Hazai ragadozó madaraink gyomor- és köpettartalom-vizsgálata. II. Baglyok. Aquila 18: 141-177.

GRESCHIK, J. 1924: Gyomor- és köpettartalomvizsgálatok. Adatok hazánk apró emlöseinek faunájához. - Aquila 30-31: 243-263.

HAitLinger, R. 1973: To the Knowledge of Siphonaptera and Anoplura Fauna of the Small Mammals in Hungary. - Parasit. Hung. 6: 205-213.

HeltAi, M. LANSZKi, J. SZEMETHY, L. 2000a: Adalékok a vörösróka táplálkozásához. - Vadbiológia 7: $72-82$.

Heltai, M. Szemethy, L. BíRó, Zs. 2000b: Új fajok a hazai faunában: az aranysakál, a nyestkutya és a mosómedve Magyarországon. - Vadbiológia 7: 63-71.

HoRvÁTH, GY. 1998: Kisemlós (Mammalia) faunisztikai vizsgálatok a gyöngybagoly (Tyto alba) köpetanalízise alapján a Dráva mentén (1995-1997). - Dunántúli dolg. Term. tud. Sorozat 9: 475-488.

HoRváTH, Gy. LANSZKa, J. 2000: Két erdei habitat kisemlōs együttesének összehasonlító szünbiológiai vizsgálata. - Somogyi Múzeumok Közleményei 14: 367-374.

Jabir, H. A. BAjOMi, D. Demeter, A. 1985: New record of the black rat (Rattus rattus L.) from Hungary, and a review of its distribution in Central Europe (Mammalia). - Ann. hist.-nat. Mus. natn. hung. 77: 263-267.

KALOTÁs, Zs. 1989: Adatok a macskabagoly (Strix aluco) táplálkozásához. - Mad. Táj. 1-2: 29-35.

Kalotás, Zs. (szerk.) 1996: Nemzeti Parkjaink. Jelen és jövő. - Aqua Kiadó, Budapest, 116 pp.

Korsós, Z. MészÁros, F. 1998: Az állatvilág sokfélesége Magyarországon. - Természetvédelmi Közlemények 7: 125-133.

Kováčik, J. 1982: Trombiculid larvae (Acari) new to the Hungarian fauna. - Parasit. hung. 14: 99-101.

LANSZK J. 1999: Faunisztikai vizsgálat a Balaton-Dráva ökológiai hálózatban közvetett módszerekkel. - Somogyi Múszaki Szemle 23: 22-28.

LANSZKi J. KöRmENDi S. 1996a: Négy ragadozó emlôs faj táplálkozásökológiai vizsgálata a fonói halastó (Somogy megye) körzetében. - Állattani Közlemények 81: 73-85.

LANSZKI, J. KÖRMENDI, S. 1996b: Otter diet in relation to fish availability in a fish pond in Hungary. - Acta Theriologica 41: 127-136.

LANSZKa J. KÖRMENDi S. 1996c: A vidra tápláléka és a rendelkezésre álló haltáplálék-készlet közötti összefüggés vizsgálata egy magyarországi halastavon. - Anser 3: 9-24.

LANSZKI J. KÖRMENDI S. 1999: Ragadozó emlös életközösség táplálék-összetétele mezógazdasági területen, Somogy megyében. - Természetvédelmi Közlemények 8: 121-136.

LANSzKI, J. HELTAI, M. 2000: Az aranysakál előfordulása és téli-tavaszi táplálékösszetétele délnyugat Magyarországon. Acta Biologica Debrecina, Suppl. Oecologica Hungarica 11(1): 95.

LANSZKI, J. KöRmendI, S. 2000: Diet of a Carnivora community in the Boronka Nature Conservation Area, in Somogy County. - Somogyi Múzeumok Közleményei 14: 375-381.

LANSZKI, J. KÖRMENDI, S. HANCZ, Cs. ZALEWSKI, A. 1999: Feeding habits and trophic niche overlap in a Carnivora community of Hungary. - Acta Theriologica 44: 429-442.

LeLKeS A. 1994: A Kis-Balaton Tájvédelmi Körzet Soricidae, Muridae és Microtinae faunája. Bagolyköpet vizsgálatok alapján. Szakdolgozat. EFE Erdômérnöki Kar, Környezet-védelmi Tanszék, Sopron, $42 \mathrm{pp}$.

LELKES, A. HORVÁTH, GY. 2000: Adatok a Kis-Balaton kisemlôs faunájához, különös tekintettel az északi pocok (Microtus oeconomus) elófordulására. - Somogyi Múzeumok Közleményei 14: 359-366.

MahunKa, S. 1963: Beiträge zur Kenntnis der Milbenfauna (Acari) von Säugetiernestern. - Acta Zool. 9(3-4): 355-372.

MAHUNKA, S. MOlNOS, E. 1962: Beitrage zur Kenntniss der in Ungarn an Kleinsaugetieren und Vogeln lebenden Milben. ${ }^{-19}$. Vertebrata Hungarica 4(1-2): 177-1 82.

MAJER, J. 1992a: Boronka-melléki Tájvédelmi Körzet zoológiai felmérése (gerinces fauna) (19901991). - Dunántúli Dolg. Term. tud. Sorozat 7: 347-375.

MAJER, J. 1992b: Baláta-tó zoológiai felmérése (különös tekintettel a madárfaunára) 1989-1990. - Somogyi Múzeumok Közleményei 9: 321-328.

MARIÁN, M. 1957: A Baláta gerinces állatvilága. - Somogyi Almanach 1: 1-59.

MARIÁN, M. 1958: A Baláta ôsláp állatvilága. - Természettudományi Közlöny 3: 119-123.

MÄrZ, R. 1972: Gewöll- und Rupfungskunde. - Akademie Verlag, Berlin, 398 pp. 
MÉSzÁros, F. 1971: Vizsgálatok a hazai denevérek élốsködő fonálférgein (Nematoda). - Állattani Közlemények 58(1-4): 78-86.

MÉsZÁros, F. 1978: Parasitic Nematodes of Clethrionomys glareolus (Rodentia) in Hungary. Parasit. Hung. 11: 87-100.

MÉSZÁros, F. SUgÁr, L. 1976: Dipetalonema rugosicauda (Böhm and Supperer, 1953) nov. comb.: Occurrence in Roe Deer in Hungary. - Parasit. hung. 9: 67-71

Mitchell-Jones, A. J., Amor,, G., Bogdanovwicz, W., Kryštufek, B., Reijnders, P. J. H., Spitzenderger, F. Stubbe, M. Thissen, J. B. M. Vohralik, V. Zima, J. 1999: The Atlas of European Mammals. - T \& AD Poyser, London, 484 pp.

MOLNÁR, I. 1983: Bagolytáplálkozási adatok a Dunántúlról. - Mad.Táj. 2: 106-1 10.

MOLNÁR, I. 1994: Erdei fülesbagoly (Asio otus) táplálkozási adatai Zircből. - Mad. Táj. 2: 33.

Molnos, É. 1982: Data on Dermanyssidae (Acari) living on small mammals and birds in Hungary. - Parasit. hung. 14: 91-93.

MuRA, É. 1972: A magyarországi Apodemus-fajokban élősködő galandférgekról (Cestodes). Parasit. Hung. 5: 47-82.

MURA, É. 1974: Review of Tapeworms in Microtinae from Hungary. - Parasit. Hung. 7: 111-142.

MurAl, É. 1976: Cestodes of Bats in Hungary. - Parasit. Hung. 9: 41-62.

Mura, E. Tenora, F. 1972: Some Taeniid species (Cestoidea) parasitizing Vertebrates (Rodentia, Carnivora, Strigiformes) in Hungary. - Acta Zoologica 19(1-2): 125-132.

MurAl, É. SUGÁR, L. 1976: Vadászterületeinken elóforduló galandférgek. II. Taeniidae fajok ragadozókból: újabb Cysticercosis és Echinococcosis esetek. - Állattani Közlemények 63: 103-115.

MURA, É. SugÁR, L. HốNICH, M. 1975: Vadászterületeinken előforduló galadférgek, I. Taeniidaefajok lárvái. - Állattani Közlemények 62(1-4): 69-73.

NAGY, G. 1996: Adatok a vidra (Lutra lutra Linné, 1758) dél-balatoni elöfordulásaihoz. - Anser 3: 25-30.

NAGY, L. PINTÉR, A. 1994: Védett állatok Somogyban (Gerincesek). - Múzeumi Tájákoztató (Kaposvár) 1: 21-32.

NAciY, S. 1982: A zsákmányállatok megoszlása crdei fülesbagoly ( $\Lambda$ sio otus) köpetekben talált maradványok alapján. Mad. Táj. 2-3: 113.

NAGY, S. 1988: Gyöngybagoly (Tyto alba) táplálkozási adatok a Dunántúlról. - Mad. Táj. 1-2: 92-95.

PASZlavszKY, J. 1918: I. Vertebrata. Classis. Mammalia. In: Paszlavszky, J. (ed.): A Magyar birodalom állatvilága/Fauna Regni Hungariae/. - A K. M. Természettudományi Társulat, Budapest, 1-43 pp.

PURGER, J. J. 1996: A Boronka-melléki Tájvédelmi Körzet keleti határvidékének (Somogy megye) kisemlös faunája, gyöngybagoly, Tỳto alba (Scopoli, 1769) köpetek vizsgálata alapján. - Somogyi Múzeumok Közleményei 12: 299-302.

PURGER, J. J. 1997: A csokonyavisontai halastavak (Somogy megye) környékének kisemlős faunája, gyöngybagoly köpetek vizsgálata alapján. - Természetvédelmi Közlemények 5-6: 105-109.

Purger, J. J. 1998: A Dráva mente Somogy megyei szakaszának kisemlós (Mammalia) faunája, gyöngybagoly, Tyto alba (Scopoli, 1769) köpetek vizsgálata alapján. - Dunántúli Dolg. Term. tud. Sorozat 9: 489-500.

RAKONCZAY, Z. (szerk.) 1990: Vörös Könyv. A Magyarországon kipusztult és veszélyeztetett növény-és állatfajok. - Akadémiai Kiadó, Budapest, 360 pp.

SCHMidT E. 1967: Bagolyköpet vizsgálatok. Magyar Madártani Intézet, Budapest, 130 pp.

SCHмiDT E. 1969: Adatok egyes kisemlősfajok elterjedéséhez Magyarországon, bagolyköpet vizsgálatok alapján. - Vertebrata Hungarica 11 (1-2): 137-153.

SCHMIDT, E. 1973: Über die mengenmässige Verteilung einiger Spitzmausarten in Ungarn. - Acta Theriologica 15: 281-288.

SCHMiDT, E. 1974a: A magyarországi mezei pocok (Microtus arvalis) állomány relatív sŭrúsége 1969-71-ben bagolyköpetek vizsgálata alapián. - Aquila 78-79:1 89-196.

SCHMIDT, E. 1974b: Pele elófordulási adatok bagolyköpetekból. - Állattani Közlemények 61(1-4): 117-118.

SCHMIDT, E. 1974c: Die Verbreitung der Erdmaus, Microtus agrestis (Linné, 1761) in Ungarn. Säugetierk. Mitt. 22: 61-64.

SCHMIDT, E. 1974d: Über die Verbreitung und Wohndichte der Kleinwühlmaus (Pitymys subterraneus (De Selys-Longchamps)) in Ungarn. - Vertebrata Hungarica 15:45-52.

SCHMiDT, E. 1976: Kleinsäugerfaunistische Daten aus Eulengewöllen in Ungarn. - Aquila 82:119-144. 
SEY, O. 1964: A pézsmapocok (Ondatra zibethica) akklimatizációjának hatása belsőélősködő férgeinek összetételére. - Szegedi Tanárképző Fớiskola Tudományos Közleményei, 143-150.

SEY, O. 1965: A pézsmapocok (Ondatra zibethica) (L., 1776) magyarországi belsó élősködó férgei I. Vertebrata Hungarica 7(1-2): 153-176.

SEY, O. 1990: Recovery of Skjabinoplagiorchis ondatrae (Andrejko, 1965) (Trematoda: Plagiorchiidae) and Troglotrema srebarni Genov. 1964 (Trematoda: Troglotrematidae) from the Muskrat in Hungary. - Parasit. hung. 23: 33-38.

SEY, O. 1991: The amphistomes of Hungarian vertebrates. - Parasit. hung. 24: 59-68.

SiMON, P. 1996: Az aranysakál (Canis aureus). - Nimród 84: 46.

Somogrvári, O., DOMBr, I. 2001: Adatok Somogy megye denevérfaunájához. - Somogyi Múzeumok Közleményei (megjelenés alatt).

SUGÁR, L. 1976a: Seasonal Incidence of Larvae of Pharyngomyia picta (Meigen) 1824 and Cephenemyia auribarbis (Meigen) 1824 (Oestridae) in Red Deer (Cervus elaphus hippelaphus) in Hungary. - Parasit. Hung. 9: 73-84.

SUGÁR, L. 1976b: On the Incidence of Larvae of Hypodermatidae in the Games and Wild Rodents of Hungary. - Parasit. Hung. 9: 85-96.

SuGÁr, L. 1978: Dicrocoelium dendriticum (Stiles et Hassal, 1896) előfordulása és jelentôsége vadállományunkban. - Parasit. Hung. 11: 145-146.

SUGÁR L. MATSKÁSI I. 1978: Isthmiomorpha melis (Schrank, 1788) és Alaria alata (Goeze, 1782) métely-fajok hazai vadon éló ragadozókból. - Parazit. Hung. 11 : 142.

SugÁr L. MéSZÁros F. 1975: Szarvasfélék kötōszövetében élősködő filáriák elöfordulása Magyarországon. - Állatani Közlemények 62(1-4): 115-117.

SzABÓ, I. 1965: The Hosts of Flea Species (Siphonaptera) in Hungary Il. - Vertebrata Hungarica $8(1-2): 167-180$.

SzABÓ, I. 1969: On the Coexistence of Fleas (Siphonaptera) on Mammals in Hungary. - Parasit. Hung. 2: 79-118.

SzAPpanos, A. PAPp, L. 1991: Bot flies and warble flies (Diptera: Gasterophilidae, Oestridae, Hypodermatidae) in the collection of the Hungarian Natural History Museum. II. Larvae. Parasit. hung. 24: 89-98.

SzEMETHY L. HeLtAi M. 1996: Néhány védett emlös ragadozó faj helyzete Magyarországon, 19871994. - Vadbiológia 5: 1-17.

TeERINK, B. J. 1991: Hair of West European mammals. - Cambridge University Press, Cambridge, 224 pp.

TOPÁl, GY. 1956: The Movements of Bats in Hungary. - Ann. hist.-nat. Musei natn. Hung. 7: 477-489.

TOPÁL, GY. 1962: A magyarországi denevérek ivararánya. - Vertebrata Hungarica 4: 141-163.

UJHELYI, P. 1989: A magyarországi vadonélő emlősállatok határozója. (Küllemi és csonttani bélyegek alapján). - A Magyar Madártani Egyesület kiadványa, Budapest, 185 pp.

YALDEN, D. W. 1977: The Identification of remains in Owl Pellets. - An Occasional Publication of the Mammal Society, No. 2, Reading, 9 pp.

Yalden, D. W. Morris, P. A. 1990: The Analysis of Owl Pellets. - An Occasional Publication of the Mammal Society, No. 13, London, 24 pp.

VÁSÁRHELYI, I. 1939: Beiträge zur Kenntnis der Säugetier-Fauna Ungarns. - Fragmenta Faunistica Hungarica 2(4): 53-54.

ZÖRÉNYI M. 1990: A bagolyköpetekból várható hazai emlósfajok határozókulcsa. - Babits füzetek 1, Babits Mihály Múvelódési Központ, Szekszárd, 33 pp. 


\title{
The mammal fauna of Somogy county (Mammalia)
}

\author{
József Lanszki \& Jenö J. Purger
}

The mammal research of Somogy county started at the beginning of the 20 th century. At first it linked to protected areas, and the researchers applied live trapping methods for small mammals and stomach analysis of predatory birds. Later faunistical studies were carried out partially with indirect methods: analysis of owl pellets and scat analysis at carnivores. Moreover, at the end of the century, the biomonitoring of the important mammal species started with questionnaire and live trapping methods. The relationship between the otter or the terrestrial predators and their dominant prey was studied. In Somogy county the occurrance of $68 \mathrm{mammal}$ species representing $80 \%$ of the Hungarian fauna have been reported among the 85 species found in Hungary. 8 of them are Insectivora, 18 Chiroptera, 2 Lagomorpha, 22 Rodentia, 14 Carnivora and 4 Artiodactyla. Due to the environmental conditions of the county, presumably some species will disappear in the future. There are some species (mainly Chiroptera) which are not represented in our list because their research is incomplete.

\author{
Authors' address: \\ Józesf LANSZKI \\ University of Kaposvár \\ Faculcity of Animal Science \\ H-7400 Kaposvár \\ Guba S. u. 40. \\ HUNGARY \\ Dr. Jenô J. Purger \\ Department of Zootaxonomy and Synzoology, \\ Biological Institute, University of Pécs \\ H-7624 Pécs \\ Ifjúság u. 6. \\ HUNGARY
}

